\section{THE INTERNATIONAL CATALOGUE} CONFERENCE.

THE preliminary proceedings of the Conference organ ised by the Royal Society to consider the preparation and publication of an International Catalogue of Scientific Literature, were reported in last week's NATURE. The Conference was brought to a conclusion on Friday, and we are now able to give the official report of the Acta in the three languages in which it is indited. From this report it will be seen that the Conference has laid a sound basis for the greatest scientific bibliography ever contemplated. The Royal Society is to be warmly congratulated upon the initiative it has taken in the matter, and the whole scientific world will be gratified at the international spirit shown in the subjoined resolutions -a spirit which prevailed throughout the Conference.

Opening Meeting, Tuesday, July 14, 1896, I I a.m., at the Rooms of the Royal Society, Burlington House.

The resolutions prepared by the International Catalogue Committee of the Royal Society to serve as a basis for discussion were taken into consideration, and the following resolutions were agreed to nemine contradicente:-

(I2) That it is desirable to compile and publish by means of some international organisation a complete catalogue of scientific literature, arranged according both to subject-matter and to authors' names.

Qu'il est désirable de compiler et de publier à l'aide d'une organisation internationale un catalogue complet de littérature scientifique classé suivant les sujets et les noms des auteurs.

Es ist wünschenswert vermittelst einer internationalen Organisation einen vollständigen Katalog der wissenschaftlichen Litteratur zusammenzustellen und zu veröffentlichen, geordnet sowohl nach dem Inhalt als auch nach den Namen der Verfasser.

(I3) That in preparing such a catalogue regard shall, in the first instance, be had to the requirements of scientific investigators, to the end that these may, by means of the catalogue, find out most easily what has been published concerning any particular subject of inquiry.

Qu'en préparant le catalogue on aura avant tout égard aux besoins des travailleurs scientifiques afin que ceux.ci puissent à l'aide de ce catalogue trouver tacilement ce qui a été publié concernant les recherches sur quelque sujet que ce soit.

Bei der Vorbereitung eines solchen Katalogs soll in erster Linie Rücksicht genommen werden auf die Beduirfnisse wissenschaftlicher Forscher, so dass dieselben mit Hülfe dieses Katalogs sich leicht in der Litteratur über irgend einen besondern Gegenstand der Forschung orientiren können.

(I4) That the administration of such a catalogue be entrusted to a representative body, hereinafter called the International Council, the members of which shall be chosen as hereinafter provided.

Que l'administration d'un tel catalogue soit confié à un corps représentatif, sous le nom de Conseil International, dont les membres seront choisis d'après les décisions prises ultérieurement.

Die Administration eines solchen Katalogs soll einer repräsentativen Körperschaft übertragen werden (die weiterhin "the International Council" genannt wird) deren Mitglieder in einer später zu bestimmenden Weise gewählt werden sollen.

(I5) That the final editing and the publication of the catalogue be entrusted to an organisation, hereinafter called the Central International Bureau, under the direction of the International Council.

Que l'édition définitive et la publication du catalogue soient confiées à une organisation nommée plus tard le Bureau Central International sous la direction du Conseil International.

Die Herausgabe und Veröffentlichung des Katalogs soll, unter der Leitung des International Council, einer Organisation anvertraut werden, die hier "Central International Bureau" genannt wird.

(16) That any country which shall declare its willingness to undertake the task shall be entrusted with the duty of collecting, provisionally classifying, and transmitting to the central Bureau, in accordance with rules laid down by the International Council, all the entries belonging to the scientific literature of that country.

NO. I 395, VOL. 54]
Que l'on charge chaque pays, qui se déclarera prêt à entreprendre cette tâche, de collectionner, de classer provisoirement, et de transmettre au Bureau Central selon les règles formulées par le Conseil International, tous les matériaux necessaires pour la bibliographie de la littérature scientifique de ces pays.

Jedes Land welches sich bereit erklärt, an der Arbeit theilzunehmen, soll mit der Aufgabe betraut werden, in Ueberein. stimmung mit den von dem International Council vorgeschriebenen Regeln, das Material iber alle einschlägigen wissenschaftlichen Veröffentlichungen des betreffenden Landes zu sammeln, provisorisch zu klassifiziren und dem centralen Bureau zu iibermitteln.

(I7) That in indexing according to subject-matter regard shall be had, not only to the title (of a paper or book), but also to the nature of the contents.

Que,dans le classement du catalogue d'après la nature des sujets, on aura égard non seulement aux titres d'un article ou d'un livre, mais aussi à la nature de son contenu.

Bei der Aufzeichnung der Abhandlungen und Bücher soll nicht nur der Titel derselben sondern auch der Inhalt beriicksichtigt werden.

(I8) That the catalogue shall comprise all published original contributions to the branches of science hereinaffer mentioned, whether appearing in periodicals or in the publications of Societies, or as independent pamphlets, memoirs, or books.

Que le catalogue comprendra toutes les contributions originales aux différentes branches de la science telles qu'elles sont mentionnées ci-après, paraissant soit dans les revues, ou dans les publications des sociétés, ou comme brochures indépendantes, mémoires, ou livres.

Der Katalog soll alle Original-Abhandlungen aus den weiter unten angeführten Wissenszweigen umfassen, gleichviel ob dieselben in Zeitschriften oder in. Veröffentlichungen von Vereinen erschienen sind, oder in Form von Flugschriften, selbständigen Aufsïtzen oder Büchern.

Second Meeting, Wednesday, July 1 5, 1896, 10 a.m., at the Rooms of the R'oyal Society, Burlington House.

(19) It having been proposed-

That a contribution to science for the purposes of the catalogue be considered to mean a contribution to any of the mathematical, physical or natural sciences, the limits of the several sciences to be determined hereafter-

Que devront entrer dans le catalogue toutes les contributions aux sciences mathématiques, physiques ou naturelles, les limites des différentes sciences étant détérminées ultérieurement.

In den in Rede stehenden Katalog sollen alle wissenschaftlichen Beiträge zur Mathematik und zu den Naturwissenschaften aufgenommen werden; die Abgrenzung der verschiedenen Wissenschaften ist weiterhin festzustellen.

The following amendment was moved, and, after discussion, adopted :-

That the terms of the resolution be referred to a Committee, consisting of Messrs. Armstrong, Billings, Darboux, Korteweg, Möbius, and Schwalbe, to report to the Conference at the opening meeting, on July 16.

The following resolutions were then agreed to nemine contradicente :-

(20) That in each country the system of collecting and preparing material for the catalogue shall be subject to the approval of the International Council.

Que la méthode employée pour réunir et préparer le matériel du catalogue dans chaque pays sera soumise à l'approbation du Conseil International.

Es soll das System, nach welchem das Material für dem Katalog in jedem Lande gesammelt und vorbereitet wird, der Zustimmung des Internationalen Ausschusses unterworfen sein.

(2I) That in judging whether a publication is to be considered as a contribution to science suitable for entry in the catalogue, regard shall be had to its contents, irrespective of the channel through which it is published.

Que pour juger si une publication doit être considérée comme propre a être admise dans le catalogue, on aura égard à son contenu, indépendamment du lieu et de la forme de la publi cation.

Bei der Beurtheilung, ob ein Beitrag zur Eintragung in de 
Katalog geeignet ist, soll der Inhalt berücksichtigt werden ohne Ruicksicht auf den Ort oder die Art der Veröffentlichung.

(22) That the Central Bureau shall issue the catalogue in the form of "slips" or "cards," the details of the cards to be hereafter determined, and the issue to take place as promptly as possible. Cards corresponding to any one or more branches of science, or to sections of such sciences, shall be supplied separately at the discretion and under the direction of the Central Bureau.

Que le Bureau Central éditera le catalogue sous la forme de fiches, le détail des fiches devant être déterminé ultérieurement, et la publication devant avoir lieu le plus promptement possible; les fiches relatives à une ou plusieurs sciences ou à l'une des sections de ces sciences seront fournies séparément au publie sous la discretion et à la direction du Bureau Central.

Das Central-Bureau soll den Katalog in der Form von "Papierstreifen" oder "Karten" ausgeben; die Details für diese Karten sollen später näher bestimmt werden ; die Ausgabe soll so rasch als möglich geschehen; Karten, welche zu der einen oder andern Wissenschaft, oder zu Abtheilungen derselben gehören, sollen mit Zustimmung und auf Anordnung des Central-Ausschusses separat verabfolgt werden.

(23) That the Central Bureau shall also issue the catalogue in book form from time to time, the entries being classified according to the rules to be hereafter determined.

That the issue in the book form shall be in parts corresponding to the several branches of science, the several parts being supplied separately, at the discretion and under the direction of the Central Bureau.

Que le Bureau Central publiera, de temps en temps, le catalogue sous le forme de livre, les titres étant classés selon les règles qui seront déterminées ultérieurement.

Que la publication sous forme de livre sera divisée en parties correspondant aux diverses branches des sciences, les uiverses parties pouvant être fournies séparément, sur demande.

Das Central-Bureau soll auch, von Zeit zu Zeit, den Katalog in Buchform herausgeben und sollen die Titel nach weiterhin zu bestimmenden Regeln klassifizirt werden.

Die Herausgabe in Buchform soll in Abtheilungen geschehen welche den einzelnen Wissenschaften entsprechen, und sollen die Theile auf Verlangen einzeln verabfolgt werden.

(24) General Ferrero having moved

That the Central Bureau be located in London-

The resolution was seconded by M. Darboux, supported by Messrs. Möbius, Heller, Weiss, Simon Newcomb, Otlet, Duka, Bourcart, Dahlgren, and Korteweg, and accepted by acclamation.

\section{Third Meeting, Thursday, July 16, 1896, at the Rooms of the} Royal Society, Burlington House.

The appointment of Prof. Liversidge, F.R.S., as official delegate representing New South Wales, was notified.

(25) The following resolutions were agreed to nemine contradicente:-

That a contribution to science for the purposes of the cata logue be considered to mean a contribution to the mathematical, physical, or natural sciences, such as, for example, mathematics, astronomy, physics, chemistry, mineralogy, geology, botany, mathematical and physical geography, zoology, anatomy, physiology, general and experimental pathology, experimental psycho$\operatorname{logy}$ and anthropology, to the exclusion of what are sometimes called the applied sciences-the limits of the several sciences to be determined hereafter.

Devront entrer dans le catalogue toutes les contributions aux sciences mathématiques, physiques, et naturelles ; par exemple : Mathématique, astronomie, physique, chimie, minéralogie, géologie, géographie mathématique et physique, botanique, zoologie, anatomie, pathologie générale et expérimentale, psychologie expérimentale, physiologie et anthropologie, à l'exclusion de ce qu'on nomme parfois sciences appliqués; les limites des différentes sciences seront déterminées uiltérieurement.

In den in Rede stehenden Katalog sollen alle Beiträge zur Mathematik und zu den Natur-Wissenschaften aufgenommen werden, wie (z. B.) zur Mathematik, Astronomie, Physik, Chemie, Mineralogie, Geologie, zur Mathematischen und Physikalischen Geographie, zur Botanik, Zoologie, Anatomie, Physiologie, Allgemeinen und Experimental-Pathologie, Psychophysik und Anthropologie, unter Ausschluss der sog. angewandten Wissenschaften;-wobei die Abgrenzung der einzelnen Gebiete noch in der Folge festzulegen ist.

(26) That the Royal Society be requested to form a Committee to study all questions relating to the catalogue referred to it by the Conference, or remaining undecided at the close of the present sittings of the Conference, and to report thereon to the Governments concerned.

La Société Royale est priée de créer une Commission ; celleci sera chargée d'étudier toutes les questions relatives au Catalogue, qui lui sont renvoyés par la Conférence et celles qui n'ont pas été résolues définitivement dans la Conférence, et de faire rapport sur le sujet aux gouvernements intéressés à l'entreprise.

Die Royal Society wird ersucht, ein Comité zu bilden, mit dem Auftrag, alle Fragen, welche ihr von der Conferenz vorgelegt werden und alle welche noch nicht definitiv festgelegt sind, auszuarbeiten und dariber an die beteiligten Regierungen zu berichten.

(27) Since it is probable that, if organisations be established in accordance with Resolution 16 , the Guarantee Fund required for the Central Bureau can be provided by voluntary subscriptions in various countries, this Conference does not think it necessary at present to appeal to any of the Governments represented at the Conference for financial aid to the Central Bureau.

L'organisation prévue à la résolution $\mathbf{} 6$ rendant probable que le fonds de garantie nécessaire au Bureau Central pourra être fourni par des souscriptions particulières dans différents pays, la Conférence estime qu'il n'est pas indispensable pour le moment de faire appel à l'aide financière des Crouvernements intéressés.

Insoferne voraussichtlich Einrichtungen im Sinne von Resolution I6 getroffen werden, erscheint es möglich, einen Garantiefonds fuir das Centralbureau durch freiwillige Zeichnung in den verschiedenen Ländern aufzubringen, und es glaubt daher die gegenwärtige Conferenz dass es zur Zeit nicht notwendig für das ist Centralbureau die finanzielle Unterstiitzung irgend einer der bei der Conferenz vertretenen. Regierungen in Anspruch zu nehmen.

Fourth Meeting, Friday, July 17, 1896, at the Rosms of the Royal Society, Burlington House.

The following resolutions were agreed to nemine contra. dicente:-

(28) The Conference being unable to accept any of the systems of classification recently proposed, remits the study of classifications to the Committee of organisation.

Le Conférence ne pouvant accepter aucune des systèmes de classification récemment proposés renvoie l'étude des classifications au Comité d'organisation.

Die Conferenz kann keine der verschiedenen in der letzten Zeit vorgeschlagenen Classifications-Systemen annehmen und überträgt desshalb die Ausarbeitung von Classificationen dem Organisationns-Comité.

The Belgian delegates expressly desired that it be placed on record that they abstained from voting on this resolution.

(29) That English be the language of the two catalogues, authors' names and titles being given only in the original languages except when these belong to a category to be determined by the International Council.

L'anglais sera la langue des deux catalogues. Toutefois les noms d'auteurs et les titres des mémoires seront donnés seulement dans la langue originale à moins que cette langue n'appartienne à une catégorie qui sera déterminée par le Conseil International.

Es soll Englisch die Sprache der beiden Cataloge sein. Die Namen der Verfasser und die Titel sollen indessen ausschliesslich in der Original-Sprache veröffentlicht werden, ausgenommen in den von dem Internationalen Ausschuss zu bestimmenden Fällen.

(30) That it be left to the Committee (of the Rayal Society) to suggest such details as will render the catalogue of the greatest possible use to those unfamiliar with English.

Le Comité aura à proposer tous les détails qui seraient de nature a rendre plus facile l'usage du catalogue dans les pays de langues étrangères à la langue anglaise.

Es wird dem Comité der Royal Society iiberlassen, alle Anordnungen zu treffen welche den Gebrauch des Cataloges für die nichtenglischen Sprachen zu erleichtern geeignet sind. 
(3I) That it is desirable that the Royal Society should be informed, at a date not later than January I, I 898 , what steps (if any) are being taken, or are likely to be taken, in the countries whose Governments are represented at the Conference, towards establishing organisations for the purpose of securing the end had in view in Resolution 16.

Qu'il est désirable que la Société Royale reçoive communication, au plus tard le $\mathrm{I}^{\mathrm{er}}$ janvier, 1898 , des démarches qui ont été prises ou seront prises par les gouvernements des pays représentés à la Conférence pour l'exécution de la résolution I6.

Es ist wünschenswerth, dass die Royal Society nicht später als bis zum I. Januar I 898, darüber verständigt werde, welche Schritte von Seiten der Länder welche Delegirte ' zur Versamm. lung gesendet haben gethan oder in Aussicht genommen sind, um Einrichtungen zu treffen welche die Durchfiihrung des Beschlusses 16 ermöglichen.

(32) That the Delegates, in reporting to their respective Governments the Proceedings of the Conference, should call immediate attention to Resolutions 16 and $3 \mathbf{I}$.

Que les délégués sont invités en faisant rapport à leurs gouvernements à attirer spécialement l'attention sur les résolutions 16 et 31 .

Die Delegirten wollen in den Berichten an ihren Regierungen über den Verlauf der Versammlung, die besondere Aufmerksamkeit auf die-Beschliisse I 6 und 31 lenken.

(33) That January I, I900, be fixed as the date of the beginning of the catalogue.

Que le début du catalogue soit fixé au I $^{\text {er }}$ janvier, 1900.

Es soll der I. Januar I900 als Datum für den Anfang des Cataloges festgesetzt werden.

(34) That the Royal Society be requested to undertake the editing, publication, and distribution of a verbatim report of the Proceedings of the Conference.

La Société Royale est prié de se charger de la confection, de la publication, et de la distribution d'un compte rendu textuel des travaux de la Conférence.

Die Royal Society wird ersucht, die Abfassung, Veröffentlichung und Versendung eines wörtlichen Berichtes der Verhandlungen der Conferenz zu übernehmen.

(35) That the proces verbal of the Conference be signed by the President and Secretaries.

(36) That this Conference requests the Royal Society to express to the Lord Mayor of London and to Dr. L. Mond their grateful, hearty appreciation of the hospitality shown by them to the Delegates.

(37) On the motion of M. Darboux, a vote of thanks to Sir John Gorst, for presiding over the Conference and his conduct in the chair, was passed by acclamation.

(38) On the motion of Prof. Weiss, a vote of thanks to the Royal Society, for their cordial reception of the Delegates, was unanimously carried.

$$
\text { Signed }\left\{\begin{array}{l}
\text { John E. Gorst, President. } \\
\text { Henry E. ARMSTRONG } \\
\text { WALTHER DYCK } \\
\text { F. A. FOREL. }
\end{array}\right\} \text { Secretaries. }
$$

\section{ARCHAEOLOGICAL STUDIES IN MEXICO.}

M R. WILliam H. HOLMES, who has been so long $\mathrm{NI}$ and favourably known in connection with the Smithsonian Institute at Washington, has lately been placed in charge of the Department of Anthropology at the Field Columbian Museum at Chicago, and has now issued from his department the first volume of what promises to be a most interesting series of anthropological publications.

Soon after Mr. Holmes had moved to his new post, Mr. Alison Armour, of Chicago, who takes a keen interest in archæological studies, invited "(to quote from $\mathrm{Mr}$. Holmes's preface) a number of " gentlemen representing different branches of scientific research to accompany him in his steam yacht Ituna on a voyage to Mexico. Three months were spent in that most interesting country, mainly in the States of Yucatan, Chiapas, and Oaxaca. The writer (Mr. Holmes) was a member of the NO. I 395, VOL. 54] party, and, as Curator of Anthropology in the Field Columbian Museum, was expected to examine and describe such archæologic remains as happened to be encountered during the journey."

Mr. Holmes made excellent use of his opportunities, and we now have the first instalment of his Report, intituled "Archæological Studies among the Ancient Cities of Mexico," dealing particularly with the monuments of Yucatan.

After an introductory chapter (with excellent illustrations), which treats of the materials and methods used in construction of Maya buildings, Mr. Holmes describes in turn the different groups of ruins which were visited, beginning with those on the islands lying close to the eastern coast of the peninsula, Mugeres, Cancun, and Cozumel. An excellent reproduction of a photograph, taken by Mr. E. H. Thompson, shows the very curious portal of a small temple on the last-named island, with one of the two supporting columns formed of a kneeling human figure.

On first opening Mr. Holmes's report I turned over the pages hastily to find an account of the ruins of Tuloom, but was doomed to disappointment. On page 75 is the following paragraph: "The most important group of ruins on the east coast of Yucatan, so far as the remains have been reported, is that known as Tuloom. It is situated on a high bluff overlooking the sea, some twenty-five miles south-west of San Miguel, the main settlement of the island of Cozumel. It was visited by Stephens in I840, and he has given us the only available account ${ }^{l}$ published up to date. This place must have been an important stronghold of the ancient Mayas, although it was not visited by the early Spaniards, so far as our records show. It is a remarkable circumstance that this place is held to-day by a Maya tribe which has never been permanently subdued by the Spaniards or Mexicans, and which now holds it as an outpost, being at war with the Mexican Government and with all intruders, whatsoever their nationality. At the time of our visit to Cozumel there were special symptoms of hostility, and the sub-chief, to whom the Tuloom district was entrusted by the principal chief, whose headquarters are some distance inland, had recently been summarily executed for permitting trade between his people and the inhabitants of Cozumel. It was natural, therefore, when the leading citizen of Cozumel, Don Pedro Perez, assured us that we would certainly be fired upon by the hostiles if we attempted to land, that the project of studying this ruin was abandoned."

I most fully sympathise with the travellers in their disappointment in failing to examine this important site, which, as far as I know, has never since the time of Stephens and Catherwood been visited by any one capable of giving an adequate description of the ruins.

The yacht then sailed round the north of the peninsula, and the travellers were landed at Progreso, whence a land journey was taken to visit the celebrated ruins of Uxmal, Izamal, and Chichén Itzá.

Uxmal is so easy of access, and has been so often visited, photographed, and described, that Mr. Holmes could not be expected during a short visit to discover anything which would add to our previous knowledge; but the admirably clear description which he gives of the ruins is accompanied by a plan and by a most carefully compiled panoramic view of the site, which will prove of the greatest assistance to the reader.

Plate vii. gives a photograph of an inscribed column or stela discovered by Mr. Thompson, which is of the utmost value, as so very few examples of carved hieroglyphic inscriptions have as yet been found in Yucatan, and a comparison of the Yucatec inscriptions with the numerous inscriptions found in Guatemala and Chiapas

\footnotetext{
1 Stephens' "Incidents of Travel in Yucatan," vol. i. p. 39 .
} 